\title{
Central bank equity: facts and analytics
}

\section{Sujan Bandyopadhyay ${ }^{1} \cdot$ Rishab Devnani $^{2} \cdot$ Sudipta Ghosh $^{3} \cdot$ Amartya Lahiri $^{3}$}

Accepted: 4 May 2021 / Published online: 25 May 2021

(c) Editorial Office, Indian Economic Review 2021

\begin{abstract}
How much capital should the central bank of a country hold? There is no consensus on this matter. We review the balance sheets of 45 central banks from around the world to describe actual practices. The principal findings are: (a) the average capitalasset ratio of central banks globally (net of revaluation capital which is purely an accounting entry) is 6.56 percent while the number in emerging economies is 6.96 percent; and (b) our Value-at-Risk estimates for the RBI excluding exchange rate risk indicate that the current level of the core capital of the RBI as mandated by the Jalan committee may be too low. We also discuss the policy moral hazards associated with mandating RBI equity payouts to the government.
\end{abstract}

Keywords Central bank equity · Value at risk · Policy moral hazard

JEL Classification E02 - E58 - E61

\section{Introduction}

How much capital should a central bank have? Central banks globally grapple with this while making decisions regarding how much of their profits to transfer to their ultimate owners and how much to set aside for augmenting their capital (including for contingencies funds). In most cases, the owner of central banks is the government (though there are examples such as the US Federal Reserve System, the Swiss National Bank,

We would like to thank the referees, Viral Acharya, Paul Beaudry, John Leahy, Raghuram Rajan and Anand Srinivasan for comments and discussions on this topic. All remaining errors are our responsibility. The opinions expressed here are the opinions of the authors and do not reflect the views of any organization.

Amartya Lahiri

amartyalahiri@gmail.com

1 Arizona State University, Tempe, USA

2 Independent Researcher, Mumbai, India

3 University of British Columbia, Vancouver, Canada 
South African Reserve Bank etc., who have private shareholders). Central banks transfer their financial surpluses to the government after deducting appropriate amounts to cover their operational requirements as well as putting aside funds for contingencies. The issue about the appropriate capitalization of central banks gains importance since there can potentially be a conflict between the principal owners' desire for profit-sharing for revenue reasons and the central banks' assessment of their own capital needs.

India went through precisely this kind of debate in 2018-19. The government, facing revenue constraints and fiscal deficits, started demanding a transfer of some of the Reserve Bank of India's (RBI's) capital. The demand was based on the argument that the amount of capital that the RBI was carrying on its books was way in excess of what was needed as cover against contingency risk. In response, the Board of the Reserve Bank decided to set up a committee under the Chairmanship of Bimal Jalan to review the economic capital framework of the RBI and recommend a capital structure going forward. In August 2019, the committee recommended a contingency risk buffer of 5.5-6.5 percent of the RBI balance sheet. The RBI Board accepted the recommendation and, based on the RBI balance sheet for 2018-19, identified Rs. 526.37 billion as excess risk buffers which was transferred to the government.

In this paper, we examine the issue of central bank capital both from an empirical and conceptual perspective. We examine global practices by studying the balance sheets of a cross-section of central banks from across the world. We also examine the relationship between central bank equity and variables such as the fiscal balances of the government, volatility of capital flows, non-performing assets in the banking system and income losses of the central bank. In particular, we focus on the relative position of India in these international patterns. We then compute the Value-at-Risk (VaR) of the Reserve Bank of India's (RBI's) asset holdings to determine the level of capital that the RBI should target. Lastly, we discuss some moral hazard issues associated with central bank capital structure that may impede efficient policy design if not taken board.

We should point out that a working paper version of this paper served as one of the many inputs into the Jalan committee report. While a number of the conclusions in this paper are consistent with the recommendations of the committee, some aspects are not. Aside from some empirical differences, a key conceptual disagreement is with respect to the Jalan committee recommendation of transferring excess capital to the government. Conceptually, transferring excess capital to the treasury opens the door to moral hazard issues for the central bank in conducting its monetary and credit policy. The paper elaborates on these (and other differences) with the Jalan committee report.

\section{An overview of the issues}

There are a number of issues surrounding the design of central bank capital structure. To motivate the our analysis we start by describing some of the key issues.

\subsection{Does a central bank need equity like commercial banks?}

Why does a central bank need capital? The Bank for International Settlements (BIS) describes the need for equity as being based on the need for central banks to build 
financial resources and financial strength. The goal is for the central bank to generate assets that can be used to generate a steady source of income to finance its operations and to absorb financial losses from these operations.

Commercial banks require capital to deal with valuation risks to their assets and liabilities and with operational risks. Central banks are no different. Their balance sheets are sensitive to fluctuations on both their asset and liabilities sides. Changes in domestic (foreign) interest rates, for example, alter the market value of the domestic (foreign) assets and liabilities they hold. Changes in the value of the domestic currency affect the domestic currency value of foreign assets. In addition, central banks can (and often do) make negative net profits in the process of meeting their monetary and financial policy goals. ${ }^{1}$ These losses have to be met either through borrowing or by drawing down capital. Lastly, any conflict between mandated transfers to the government (if any) and the residual surplus of the central bank that is available for transfer to the government also has to be met by either drawing down the bank's capital or by printing additional liabilities (money).

The standard way in which central banks meet these balance sheet risks is by building capital reserves. Overall central bank capital (or equity) comprises mostly of paid up capital, contingency reserves and revaluation reserves. Individual central banks may sometimes have one or two additional reserves that reflect their special needs. Out of these three types of reserves, the paid up capital is typically very small. Most of the remaining capital reserves is divided between contingency and revaluation reserves. The general practice at most central banks is to record changes in the local currency value of foreign assets due to exchange rate changes in their revaluation reserves. Revaluation reserves are essentially an accounting reserve. Contingency reserves on the other hand are reserves that are readily deployable.

There are also some counter-arguments which suggest that central banks do not necessarily need equity. First, they can always print money over which they have a monopoly. Moreover, citizens of a country are obligated to accept the money that the central bank prints. This gives central banks a unique ability to issue liabilities to fund their operations when other sources of income decline. Second, central banks can continue to operate even with negative equity since they are insulated from bankruptcy proceedings. The only entity that can liquidate a central bank is its primary shareholder - the government. Third, the government can always inject resources into the central bank to cover its balance sheet losses.

These three arguments are, however, all subject to debate. First, the increasing use of e-monies calls into question the sustainability of the monopoly role of central banks in issuing money. Second, during times of inflationary stress a number of countries have found that people switch to alternative currencies such as US dollars and avoid dealing with the local currency. Hence, a better description of the money circulation process is that people are not really forced to accept the money

\footnotetext{
1 There is a related concept of central bank structural profits. Structural profits are the difference between the present discounted value of all current and future flow net income. Central banks could also make negative structural profits. This could indicate a dynamic insolvency if the initial capital of the central bank is insufficient to cover this dynamic structural loss.
} 
issued by the central bank but rather choose to hold it. They could as easily choose to hold a different money if it proved to be a better "product". Lastly, the ability of a government to inject resources is limited by the health of its own finances. Governments with large outstanding public debt and high fiscal deficits are unlikely to be in a position to inject fresh capital into the central bank. Worse, it is precisely these types of governments that may be looking for surplus transfers from the central bank thereby calling into question the joint health of the whole financial and monetary system.

The issue of central bank capital at the end of the day cannot be removed from the issue of the operational autonomy or independence of the central bank. Capital buffers and operational independence of central banks are linked through at least three channels. First, the main source of financing for central banks is seigniorage, or real resources generated in the process of printing money. The revenue from money printing has two components. The first is the rate of expansion of the real money base while the second is the inflation tax. ${ }^{2}$ Central banks typically have a policy mandate to manage inflation. If the seigniorage revenue at the policy mandated inflation rate is insufficient to finance the central bank's operational expenses then it will make losses. These would have to be financed either through drawing down the central bank's capital reserves or by a fresh injection of resources from the government. In the absence of adequate capital reserves, such a situation would severely compromise the central bank's ability to deliver on its policy mandate and its operational independence since it would have to rely on its owner to stay afloat.

Second, in the absence of capital buffers, operational losses suffered due to fluctuating asset prices or due to quasi-fiscal losses incurred on account of operations that were needed to meet policy objectives would have to be financed using the inflation tax. This would directly compromise the central bank's ability to meet its inflation and financial objectives. Failing to deliver on its mandate is the surest way for the central bank to lose its operational independence as well.

Lastly, if the central bank relies on injection of resources by the government to make up for losses that cannot be covered by its capital base, then there will automatically be the expectation that the central bank will make fiscal transfers to the government when it has operating profits and the government needs additional revenues. This will tend to cause inflationary expectations since the inflation tax is the primary revenue source for the central bank. This will naturally weaken the ability of the central bank to deliver on its inflation target.

Is there evidence that weakened financial conditions compromise the performance of the central banks? There does indeed exist evidence that suggests that central banks with positive structural profits deliver lower inflation rates than central banks with negative structural profits (see Ize 2006; Oulidi and Ize 2009 and Stella 1997). Researchers have also found that weakening of the financial strength of central banks is accompanied by worse macroeconomic performance on inflation and

\footnotetext{
${ }^{2}$ Inflation is a tax that gets levied on the money in circulation and on the non-interest bearing component of bank reserves.
} 
on monetary policy transmission (see Adler et al. 2012; Klueh and Stella 2008 and Stella 2008).

\subsection{Should revaluations of central bank assets be transferred to the government?}

The value of central bank assets are usually marked to market. Consequently, changes in the market value of both domestic and foreign assets cause a change in the total assets of the bank. This revaluation of assets is usually accommodated on the liabilities side by a change in the revaluation capital of the central bank. A key point of recent friction between the RBI and the government was about whether the RBI should transfer increases in the revaluation capital to the treasury.

Central banks typically have multiple mandates that include managing inflation, targeting credit aggregates to facilitate economic growth, managing the exchange rate of the country's currency to facilitate external adjustment, overseeing financial stability and regulating financial entities. With such an expansive mandate, an overarching principle of prudent central bank practice is to try and avoid situations with conflicting objectives especially given the limited number of instruments that are typically available to the central bank.

A good (and often unrecognized) example of limited instruments and multiple mandates is the revaluation of central bank foreign assets due to exchange rate changes. If these revaluation changes are counted as part of the core capital of the central bank then during periods of exchange rate depreciation the amount of core capital will appear to be sub-optimally high. This can lead to demands for transferring some of these funds to the fiscal authority for either direct spending or to pursue other goals such as restructuring of banks. Given that some of these potential uses of the funds may have implications for other goals of the central bank such as inflation management or credit growth, the central bank may preempt this by preventing the exchange rate from changing. But this, in turn, could end up compromising the central bank's mandate of maintaining external balance through appropriate changes in the nominal exchange rate. A similar logic operates when there is a cut in domestic interest rates. These tend to raise the market value of treasury securities held by the central bank.

The more general point is that increases in the market value of central bank capital, whether due to depreciations of the exchange rate or due to reductions in domestic interest rates, are not realized gains. Transferring these gains to the government effectively imply monetizing the paper value of the assets. More troublingly, the demand for such transfers are asymmetric: governments want increases in the value of assets to be transferred but are loathe to recapitalize the central bank when its revaluation capital falls.

In this paper, therefore, our measure of core capital strips off revaluation reserves from the overall capital holdings of central banks. To do this, we examine the balance sheets of 45 central banks comprising both developed and emerging economies. Central banks tend to follow different methods of accounting for revaluation of assets due to exchange rate changes. Some account for the changes 
Table 1 Sample coverage by variable and country group

\begin{tabular}{llll}
\hline Averages & All countries & $\begin{array}{l}\text { Emerging } \\
\text { countries }\end{array}$ & $\begin{array}{l}\text { Devel- } \\
\text { oped } \\
\text { countries }\end{array}$ \\
\hline Capital-asset ratios & 45 & 31 & 14 \\
Fiscal balance & 41 & 28 & 13 \\
Volatility of capital flows & 41 & 28 & 13 \\
\hline
\end{tabular}

in their profit and loss accounts while others create a separate entry in their balance sheet which records this amount. We compute the core capital of each central bank in each year by netting out the exchange rate induced revaluation of capital appropriately.

\section{Central bank capital: cross-country patterns}

Our sample consists of 45 countries from around the world consisting of the 14 developed countries and 31 emerging and developing economies. Our data comes from the International Financial Statistics (IFS), the World Bank and the Annual Reports of individual country central banks. Some of the variables that are of key interest to us are central bank equity, general government fiscal balances and the volatility of capital flows. The data for central bank capital and for the general government fiscal balance is the latest available till December 2018, while the data for capital flows covers the period 2009-2017. Details on the data, its sources, computations methods are given in the "Appendix".

Table 1 gives the sample coverage of countries broken down by variable and country grouping.

\subsection{Stylized facts}

We start by computing the capital-to-asset ratio of all the 45 countries in our sample. Our measure of capital is deployable capital which is measured as total capital net of revaluation reserve funds. ${ }^{3}$ Revaluation funds are essentially an accounting entry on the liability side of the central bank balance sheet when the market value of their assets changes say due to a change in the exchange rates. However, this is a form of accounting capital rather than deployable capital. Hence, we remove this entry from the calculation of the central bank asset base. In the following we shall refer to this measure of deployable capital as "core capital"

\footnotetext{
${ }^{3}$ For India, we also removed the Asset Development Fund which is a special vehicle set up by the RBI to invest in its subsidiaries and entities that it promotes. Given its explicitly special role, we have excluded it from the funds available for contingency purposes.

${ }^{4}$ We also dropped four countries whose central banks have negative equity since these are likely to be somewhat special with distinct arrangements with their national governments. Moreover, the fact that
} 
Table 2 Cross-country sample averages

\begin{tabular}{lcccc}
\hline & All countries & Emerging countries & Developed countries & India \\
\hline Capital-asset ratios & $6.56 \%$ & $6.96 \%$ & $5.67 \%$ & $6.60 \%$ \\
Fiscal balance-GDP ratio & $-2.89 \%$ & $-3.99 \%$ & $-0.19 \%$ & $-6.60 \%$ \\
Volatility of capital flows & 0.82 & 0.90 & 0.68 & 0.54 \\
\hline
\end{tabular}

Notes:

1. Capital-asset ratios are overall capital net of revaluation reserves as a percentage of total central bank assets.

2. Fiscal balance is the difference between central government revenues and expenditures. The difference is computed as a share of GDP at current prices.

3. Volatility of capital flows is computed using current account data (in USD Mn) for all the countries in our sample set from 2009 to 2017 from the International Financial Statistics (IMF). We use the average of the 5 year rolling coefficient of variation of the current account for the years 2014-2017

Table 2 reports the average level of the core capital to total asset ratio broken down by the overall sample of countries as well as the sub-samples of developed and emerging economies. The table also reports the stylized facts of the cross-country data regarding the general government fiscal balances and the volatility of capital flows.

The average capital-asset ratio (net of revaluation capital) in our sample of countries is 6.56 percent. The capital-to-asset ratio of the Reserve Bank of India (RBI) is 6.6 percent. ${ }^{5}$ Clearly, the RBI is not over-capitalized by this average international norm. It is worth noting that central banks in developed economies tend to have smaller capital ratios. The average for the developed economies in our sample is 5.67 percent which likely reflects the greater stability of those economies. The corresponding average for emerging and developing economies is 6.96 percent. Relative to the emerging economy group, the RBI's capital base is 5 percent lower. Table 3 gives the individual capital-asset ratios of all the central banks in our sample. ${ }^{6}$

The fact that central banks in developed economies tend to hold lower levels of core capital relative to emerging economies is interesting. There are two possible explanations for it. The first is that developed economies tend to be characterized by lower economic volatility than emerging economies. The greater stability (and deeper institutions) in developed economies lowers the possibility of their central banks being called upon to provide back-stopping aid for various sectors of the

\footnotetext{
Footnote 4 (continued)

these banks have maintained negative equity levels suggests that these other arrangements have made the issue of its capital holding irrelevant for these central banks.

5 We should note that in a related paper, Anand et al. (2018) arrive at an RBI core capital estimate of 8.2 percent by including both the asset development fund as well as funds kept aside for bills payable. Both of those are clearly inappropriate to include in the contingency capital of the RBI since those are demarcated for specific purposes.

6 Including the four countries with negative equity reduces the overall international core capital ratio to 5.75 percent while reducing the developed and emerging economy averages to 4.25 percent and 6.43 percent, respectively. Clearly, the effects are marginal.
} 
Table 3 Central bank capital ratios (recent figures)

\begin{tabular}{llllll}
\hline Developed economies' central banks (in descending order) & & & \\
\hline Denmark & $14.65 \%$ & Sweden & $6.87 \%$ & Japan & $1.69 \%$ \\
Switzerland & $13.77 \%$ & ECB & $4.05 \%$ & France & $1.20 \%$ \\
Singapore & $13.42 \%$ & Netherlands & $3.05 \%$ & United States & $0.93 \%$ \\
Australia & $7.78 \%$ & Norway & $2.47 \%$ & Canada & $0.12 \%$ \\
New Zealand & $7.15 \%$ & Iceland & $2.18 \%$ & & \\
\hline Other central banks (in descending & order) & & & \\
\hline Botswana & $43.59 \%$ & India & $6.60 \%$ & Hungary & $2.26 \%$ \\
Hong Kong & $18.90 \%$ & Turkey & $6.28 \%$ & Pakistan & $1.93 \%$ \\
Bahrain, Kingdom of & $17.45 \%$ & Bosnia \& Herzegovina & $5.63 \%$ & Morocco & $1.87 \%$ \\
Croatia & $12.52 \%$ & Namibia & $5.02 \%$ & Philippines & $1.76 \%$ \\
Kenya & $11.44 \%$ & Sierra Leone & $4.68 \%$ & Netherlands Antilles & $1.70 \%$ \\
Liberia & $10.31 \%$ & Malaysia & $3.87 \%$ & Iran & $1.68 \%$ \\
Bahamas, The & $9.29 \%$ & Ghana & $3.85 \%$ & Ethiopia & $1.67 \%$ \\
South Africa & $9.25 \%$ & Myanmar & $3.69 \%$ & Romania & $1.18 \%$ \\
Indonesia & $8.31 \%$ & South Korea & $3.19 \%$ & Peru & $0.86 \%$ \\
Kyrgyz Republic & $7.04 \%$ & Bangladesh & $2.50 \%$ & Brazil & $0.75 \%$ \\
Sri Lanka & $6.70 \%$ & & & & \\
\hline
\end{tabular}

Notes:

1. The capital ratios are constructed from the financial statements and annual reports of various central banks

economy, in particular the banking system. The second explanation for the higher capital holdings of central banks in emerging economies is that keeping some of the country's assets in the hands of an "autonomous" agency such as the central bank could potentially raise the borrowing ability of the government that has a low sovereign credit rating. Intuitively, parking some assets in the central bank is a form of collateral pledging by the country. Developed countries, which have higher average credit ratings, have a lower need for this.

Table 2 also highlights a second key feature of the cross-country data. The general government (federal and state combined) fiscal deficit in India is 6.6 percent of GDP. This is about twice as large as both the overall international average as well as the emerging country average. Even more strikingly, the Indian fiscal deficit is over six-fold larger than the developed country average of 0.19 percent. The high level of the fiscal deficit in India is particularly relevant since one potential source of funds for recapitalization of the central bank (if needed) is the fiscal authority. However, if the fiscal authority is itself deeply in deficit then it is not a viable source of funds in an emergency.

Moreover, the times at which the central bank requires capital injections due to operating losses are also likely to be periods of high macroeconomic and fiscal stress, rendering the possibility of recapitalization in those states less likely. Yet another confounding aspect of relying on the fiscal authority to recapitalize the 
Fig. 1 Proportion of central banks with losses
Share of Countries with Losses

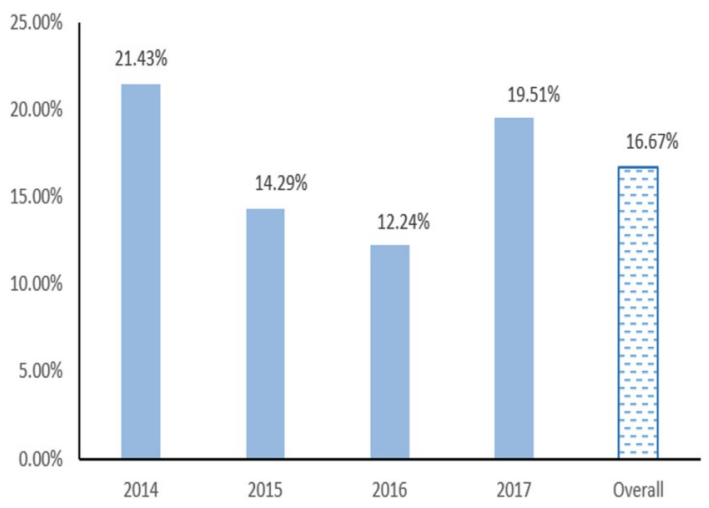

central bank in the event that its equity position becomes negative is that such an arrangement could engender expectations of a quid pro quo between the fiscal and monetary authority. This, in turn, could lead to a loss of operational autonomy of the central bank.

The main takeaway from the above comparisons is that the RBI is not over-capitalized relative to overall international standards. In fact, it is marginally undercapitalized relative to the group of emerging and developing economies.

\subsection{Do central banks suffer losses?}

Central banks use the surpluses generated from their regular operations to distribute dividends to the government or to add to their contingency reserves. Conceptually then, a central bank that has negative surpluses, i.e., it makes losses, would have to accommodate it by eliminating dividends and reducing its contingency reserve capital. The problem with having an undercapitalized central bank is that operating losses could push the central bank into negative equity territory thereby severely jeopardizing its ability to cope with operational risks.

Is the possibility of central banks suffering operating losses just a theoretical possibility? An examination of the experience of our sample countries sheds some light on this. We examined the financial accounts of the 45 countries in our sample from 2014 to 2017. Figure 1 shows the proportion of central banks with negative surpluses (or losses) in each of the 4 years that we examined. Clearly, more than one in every seven central banks suffer losses every year with the proportion becoming as high as one in five in some years.

While Fig. 2 demonstrates that central bank operating losses are fairly common, one might wonder about the size of these losses. More specifically, when losses do occur are they large or are they small relative to the size of central bank assets? Figure 2 answers this question. It plots the frequency distribution of the size of the loss as a percentage of the central bank's core capital. The average size of the loss, contingent on a central bank making a loss, was 50 percent of core capital. Underlying that average, there is a lot of variation in the size of these 
Fig. 2 Magnitude of central bank losses

Fig. 3 RBI income volatility

\section{Loss to Capital Ratio}

Mean: $49.73 \%$

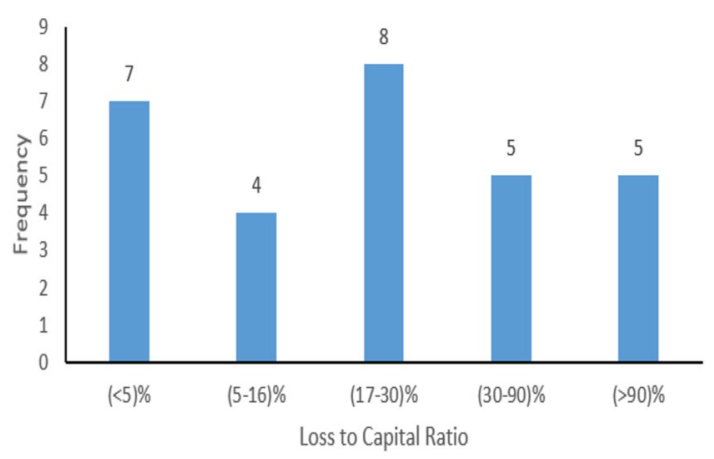

Reserve Bank of India: Income Growth

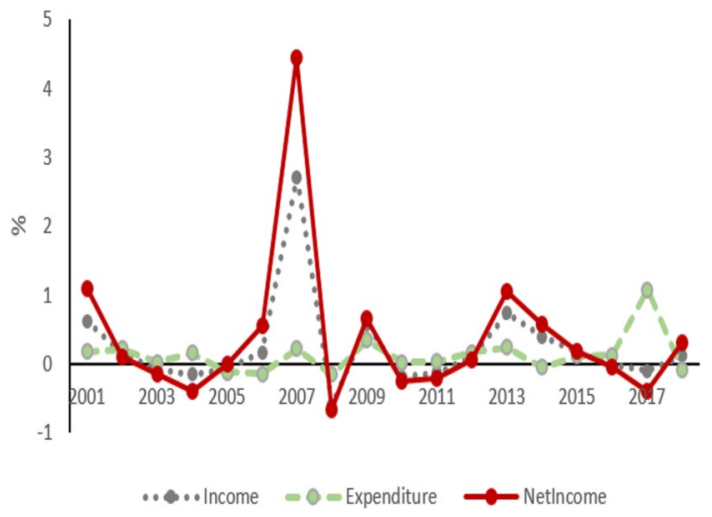

central bank losses. While the smaller losses were under 5 percent of central bank core capital, some of the bigger losses were large enough to wipe out the entire capital of those central banks. Clearly, losses, when they occur, are often not insignificant in size.

Does the RBI face income risk? Figure 3 plots the growth rate of income, expenditure and net income of the RBI since 2000 . Clearly, there is significant volatility in the RBI's net income growth series with negative growth in seven out of the last 16 years.

Table 4 shows the statistics on the mean and standard deviation of RBI's net income series between 2000 and 2018. The important number is the third row which says that a 1.29 standard deviation negative shock to RBI's net income would have implied operational losses for the RBI in 2008 and 2017. This does not appear to be an implausible event given global experiences.

The main takeaway from the above is that central bank losses are not just a theoretical possibility. Not only do they occur but they also occur often. Moreover, when 
Table 4 RBI net income summary statistics: 2000-2018

\begin{tabular}{ll}
\hline Mean & 248.79 \\
Standard deviation & 192.45 \\
Size of shock needed for negative profits & 1.29 \\
\hline
\end{tabular}

Notes:

1. Income numbers are in billions of rupees

2. A 1.29 standard deviation negative shock to its net income would have caused the RBI to have a net income loss in the years 2008 and 2017
Fig. 4 Fiscal balance and central bank capital

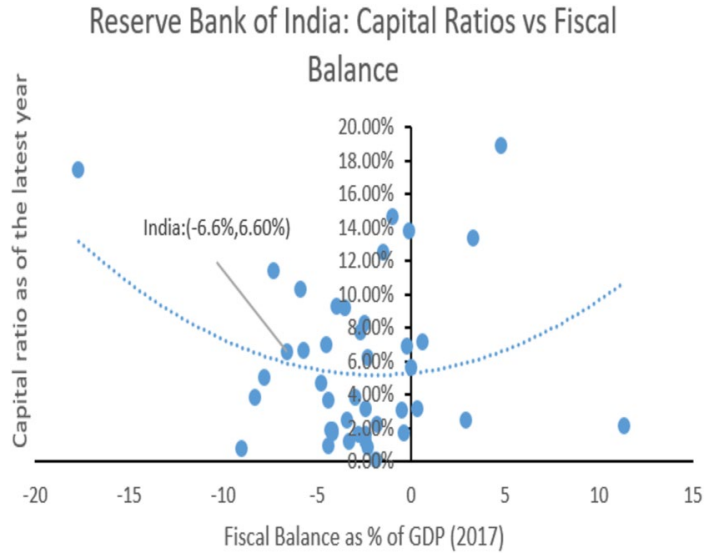

losses occur, they can also be large with the average size of the loss being almost 50 percent of core capital.

\subsection{Government fiscal balance and central bank capital}

An argument for why central banks do not need a lot of capital on their balance sheets is that the government, which is their owner, can provide capital and resources in emergencies for which the capital is typically provisioned. However, the viability of this source depends critically on the health of government fiscal balances. The weaker the state of public finances the less credible this option is. Consequently, central banks in countries where governments run large fiscal deficits may be expected to hold more capital as a form of insurance.

Figure 4 plots the scatter of general government (federal plus state governments) fiscal balances against the capital ratios for the countries in our sample. The figure reveals the anticipated pattern: central banks in countries with larger fiscal deficits tend to have larger capital ratios. The relationship appears to be best described as non-linear. The relationship is strongly negative in countries with fiscal deficits but becomes weakly positive in the small set of countries that have fiscal surpluses. 
Where does India fit in this picture? The average consolidated fiscal deficit (for the general government which combines federal and state governments) for countries in our sample in 2017 (or the latest available year) is 2.89 percent. The corresponding deficit for India was 6.6 percent, or 128 percent more than the international average. Even more disconcertingly, the fiscal deficit in India is 65 percent more than the average deficit in emerging economies.

The fact that the RBI's capital ratio is just around the global average while India's fiscal deficit is 128 percent above the global average suggests that India is undercapitalized by this metric. This follows from the observed pattern that countries with larger deficits tend to have larger capital ratios.

We now econometrically examine the core capital holdings of central banks. This approach has the benefit of allowing for a clean cross-country determination of central bank capital holdings as a function of different variables while allowing for country-specific controls.

To run our regressions, we construct a panel of countries in our sample for the period 2014-2017. We include as regressors the fiscal balance as a share of GDP, an interaction term between the fiscal balance and a dummy that indicates whether the country has a fiscal deficit, the volatility of capital flows, the net income of the central bank (net of mark-to-market gains or losses), and the share of non-performing assets in gross loans. The dependent variable is our measure of bank core capital (capital net of revaluation capital). Table 5 gives the regressions results for various specifications of bank capital.

We essentially run two sets of regressions: regressions with and without central bank net income; regressions with and without country fixed effects. The most comprehensive regression is specification 4 which includes both central bank adjusted income and country fixed effects. Two features stand out in these regressions. First, most variables appear to be insignificant in explaining the cross-country variation in core central bank capital. Second, the dummy for India is insignificant indicating that the level of core capital held by the RBI is not an outlier once we control for all the other factors.

The upshot of these results is that the cross-country variation in central bank capital is difficult to explain using standard variables. Rather, country-specific factors seem to be driving most of the cross-country variation. However, even on this country-specific margin India is not an outlier (as evidenced by the insignificant India dummy in regression specification 4 .

\section{Value at risk of the $R B I$}

So how much capital should the RBI hold? That was the original question that we started with. Our analysis thus far has revealed that the RBI's core capital base of 6.6 percent is lower than the average for emerging market economies and around the same as the international average including developed economies which tend to hold lower levels of capital. That, however, does not tell us much about the desirable level of capital that the RBI should hold. This is what we turn to next. 


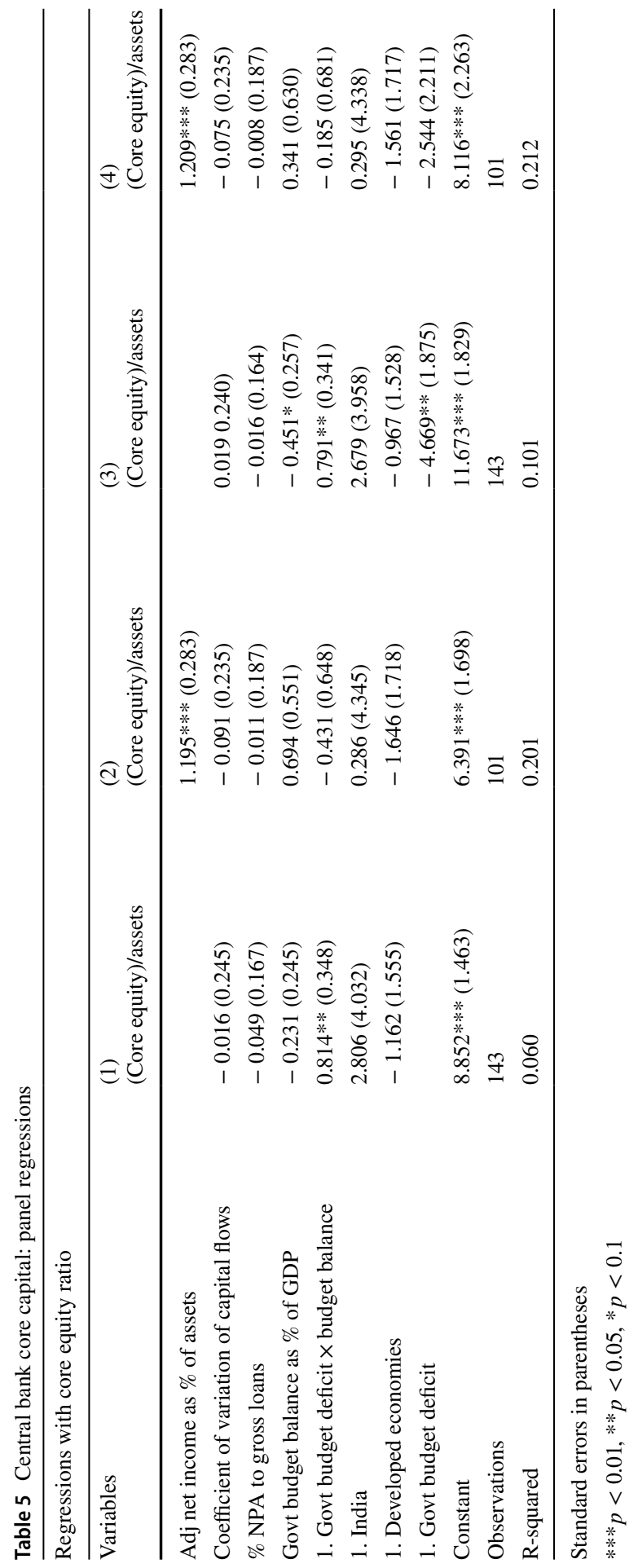


An internationally accepted method of ascertaining the recommended level of capital for commercial banks is the Value at Risk (VaR) approach. The method is simple. Over any given time horizon (10 days, 30 days, 3 months, etc.) one can compute the return on the portfolio of the bank which can then be annualized. Every negative return when multiplied by the size of the portfolio gives the size of the fall in the value of the portfolio due to that particular negative realization. The computed annualized shocks to the value of the portfolio can then be ordered in ascending order to get a whole distribution of annual losses. Clearly, negative losses would be increases in the value of the portfolio.

This computed distribution can then be used to compute the Value at Risk of the portfolio. Specifically, one can choose a particular confidence interval $x \%$ and determine the size of the $1-x \%$ largest portfolio losses. Let this computed number be $y$. This number would be interpreted as "with $x \%$ certainty the loss in value of the portfolio will be less than $y$." The higher the $x$ the greater the certainty one is demanding and consequently the greater the size of the loss that one is ruling out. Suppose one chooses the 99 percent confidence interval then $x=0.99$. In this case one is trying to pick out the largest $1 \%$ of portfolio losses. Hence, the computed number for the 99 percent confidence interval will be greater than, say, the 95 percent confidence interval.

There are a couple of other methods that are also used to compute the potential risk to portfolio which are related to the VaR approach. The first alternative is the Expected Shortfall approach or ES-VaR. This computes the total value at risk for a given confidence interval by adding up (integrating under the distribution) all the losses to left of the cutoff threshold. The VaR, in contrast, only computes the value at the chosen confidence interval threshold. Consequently, the estimated value at risk under ES-VaR will be greater than that under VaR.

A second alternative to $\mathrm{VaR}$ is the $\mathrm{S}-\mathrm{VaR}$ approach which focuses on the worst $z$ percent of all outcomes and computes the VaR for that truncated distribution. Since the worst $x \%$ outcomes under the full distribution will be lower than the worst $x \%$ outcomes under the truncated distribution of the worst $z$ percent of all outcomes say, the loss numbers computed under S-VaR will also be greater than those under VaR for the same confidence interval. The $\mathrm{S}-\mathrm{VaR}$ is a more stringent requirement than VaR which gives capital level to fend off a crisis now. Given that central banks must be credible even under stressed scenarios to fend off crises like the global financial crisis (GFC) in 2008 or the Taper Tantrum in 2013, the S-VaR may be more appropriate. Indeed, after the GFC, commercial banks are being asked to hold capital based on stress tests and not just average time loss based risk weights.

We estimated the VaR, ES-VaR and S-VaR for the RBI portfolio under the 99.9, 99 percent, 97.5 and 95 percent confidence intervals. We estimated these for returns over windows of 10 days, 30 days and 90 days. To construct the RBI asset portfolio we follow Anand et al. (2018). We assume that the RBI foreign asset portfolio is composed of 30 percent foreign currency and 70 percent foreign assets. The 
currency portfolio is assumed to be 70 percent US dollars, 20 percent Euro and 10 percent British pounds. Similarly, the asset portfolio is assumed to be 70 percent US dollar assets, 20 percent German assets and 10 percent UK assets. We assume that all assets are held in terms of 10-year government securities. Lastly, the RBI's domestic securities are assumed to be held entirely in terms of 10-year government securities. ${ }^{7}$

VaR computations require incorporating the various shocks that typically impact the value of central bank assets. One of these shocks is the value of the exchange rate as it affects the domestic currency value of the central bank's foreign assets. As we argued above, under our conceptual principle, exchange rate generated changes in the value of assets are accounting entities that should not be counted as part of core capital. Including these revaluation funds in capital also generates conflicting policy objectives as we highlighted above which makes it even more important to leave this out of any baseline measure of a central bank's core capital. In light of this, we take the following approach. For our baseline estimates, we compute VaR without incorporating exchange rate risk and compare the resultant estimates with the RBI's core capital which excludes the revaluation capital. We then conduct a second set of computations wherein we estimate the VaR of the RBI asset base by including exchange rate risk. These estimates are then compared with the RBI's overall capital base which includes the revaluation capital.

To compute actual returns on the portfolio, we take the bond's clean price index value $P_{i, t}$, get negative return over $h$-day window, so that losses are on the right tail and profits are on the left. ${ }^{8}$

$$
r_{i, t}=-\left(\frac{P_{i, t}}{P_{i, t-h}}-1\right)
$$

We then annualize the above return as:

$$
a r_{i, t}=\left(1+r_{i, t}\right)^{\frac{252}{h}}-1
$$

where 252 is the usual number of trading days per year in global markets.

Lastly, we compute the loss-to-asset ratio as

$$
\text { LTA }_{i, t}=\frac{\text { Bonds held on balance sheet }_{i, t} * a r_{i, t}}{\text { Total Assets }} * 100
$$

\footnotetext{
7 We are forced to follow this ad-hoc assumption of Anand et al. (2018) regarding the portfolio composition of the RBI due to unavailability of its portfolio composition data.

${ }^{8}$ We use the clean price index instead of the total return index, so that our constructed losses on the bonds are not contaminated by recent coupon payments, and only reflect daily changes in yields. For India, this index is CCIL's Principal Return Index, while for the USA it is provided by Barclays for government bonds in the 10-year maturity bracket, and for Germany and the UK in the 7-10-year maturity bracket. For the VaRs excluding exchange rate risk, the indices are computed in the local currency of the bond while for VaRs including exchange rate risk we use rupee value of the bonds.
} 
Table 6 Capital required to cover market risk, as percent of total assets, January 2013-November 2018

\begin{tabular}{llllllllll}
\hline CI & $\begin{array}{l}\text { 10-day } \\
\text { VaR }\end{array}$ & $\begin{array}{l}\text { 10-day } \\
\text { ES-VaR }\end{array}$ & $\begin{array}{l}\text { 10-day } \\
\text { S-VaR }\end{array}$ & $\begin{array}{l}\text { 30-day } \\
\text { VaR }\end{array}$ & $\begin{array}{l}\text { 30-day } \\
\text { ES-VaR }\end{array}$ & $\begin{array}{l}\text { 30-day } \\
\text { S-VaR }\end{array}$ & $\begin{array}{l}\text { 90-day } \\
\text { VaR }\end{array}$ & $\begin{array}{l}\text { 90-day } \\
\text { ES-VaR }\end{array}$ & $\begin{array}{l}\text { 90-day } \\
\text { S-VaR }\end{array}$ \\
\hline 95 & 29.0 & 42.5 & 49.9 & 17.1 & 23.3 & 28.1 & 8.3 & 13.1 & 16.9 \\
97.5 & 38.9 & 51.7 & 55.4 & 21.9 & 27.5 & 29.8 & 12.2 & 16.3 & 18.2 \\
99 & 49.9 & 64.0 & 78.3 & 28.1 & 31.2 & 31.9 & 16.9 & 18.2 & 18.7 \\
99.99 & 99.8 & 99.8 & 99.8 & 41.6 & 41.6 & 41.6 & 19.4 & 19.4 & 19.4 \\
\hline
\end{tabular}

Notes:

1. ES-VaR is the simple mean of losses in the right tail beyond the VaR cutoff

2. S-VaR is VaR among the worst $20 \%$ of losses

Table 7 Capital required to cover market risk, as percent of total assets, January 2014-November 2018

\begin{tabular}{llllllllll}
\hline CI & $\begin{array}{l}\text { 10-day } \\
\text { VaR }\end{array}$ & $\begin{array}{l}\text { 10-day } \\
\text { ES-VaR }\end{array}$ & $\begin{array}{l}\text { 10-day } \\
\text { S-VaR }\end{array}$ & $\begin{array}{l}\text { 30-day } \\
\text { VaR }\end{array}$ & $\begin{array}{l}\text { 30-day } \\
\text { ES-VaR }\end{array}$ & $\begin{array}{l}\text { 30-day } \\
\text { S-VaR }\end{array}$ & $\begin{array}{l}\text { 90-day } \\
\text { VaR }\end{array}$ & $\begin{array}{l}\text { 90-day } \\
\text { ES-VaR }\end{array}$ & $\begin{array}{l}\text { 90-day } \\
\text { S-VaR }\end{array}$ \\
\hline 95 & 24.8 & 34.8 & 42.4 & 12.9 & 16.3 & 18.4 & 7.0 & 7.9 & 8.5 \\
97.5 & 32.1 & 41.3 & 47.9 & 15.6 & 18.4 & 20.7 & 7.8 & 8.4 & 8.9 \\
99 & 42.4 & 48.7 & 53.0 & 18.4 & 20.3 & 21.9 & 8.5 & 9.0 & 9.4 \\
99.99 & 66.8 & 66.8 & 66.8 & 22.6 & 22.6 & 22.6 & 9.7 & 9.7 & 9.7 \\
\hline
\end{tabular}

Notes:

(1) ES-VaR is the simple mean of losses in the right tail beyond the VaR cutoff

(2) S-VaR is VaR among the worst $20 \%$ of losses

Table 6 shows the estimated value at risk (excluding exchange rate risk) of the RBI's asset portfolio for different confidence intervals and time horizons. Our sample period is January 2013-November 2018. The key feature that stands out from the $\mathrm{VaR}$ calculations is that the current core capital of the RBI at 6.6 percent is significantly lower than the estimated asset values of the RBI that are at risk for all confidence intervals, for all time horizons and for all methods. Even a 30-day horizon $\mathrm{VaR}$ estimate at the 95 percent confidence interval is 17.1 percent which is over 150 percent greater than the current core capital of the RBI.

Perhaps most strikingly, the 10-day return horizon VaR, ES-VaR and S-VaR estimates are all greater than even the overall capital of the RBI (including the revaluation capital fund) even at the 95 percent confidence interval. Indeed, at the 97.5 percent confidence interval the 10-day return horizon VaR estimate is 38.9 percent which is 11 percentage points more than the RBI's current overall capital holding including its revaluation capital!

One might wonder if our VaR estimates are high due to our using the sample period 2013-18 which includes the taper tantrum of 2013. At some level, episodes such as the taper tantrum are precisely the kinds of events for which the central bank needs to have capital. Nevertheless, we estimate the sensitivity of our VaR estimates to the sample period in two alternative ways. First, we use the sample period 2014-18 to re-estimate the VaR numbers reported in Table 6. These are reported in Table 7. Next, we re-estimate the VaR using only the 2017-18 data. These numbers 
Table 8 Capital required to cover market risk, as percent of total assets, April 2017-November 2018

\begin{tabular}{llllllllll}
\hline CI & $\begin{array}{l}\text { 10-day } \\
\text { VaR }\end{array}$ & $\begin{array}{l}\text { 10-day } \\
\text { ES-VaR }\end{array}$ & $\begin{array}{l}\text { 10-day } \\
\text { S-VaR }\end{array}$ & $\begin{array}{l}\text { 30-day } \\
\text { VaR }\end{array}$ & $\begin{array}{l}\text { 30-day } \\
\text { ES-VaR }\end{array}$ & $\begin{array}{l}\text { 30-day } \\
\text { S-VaR }\end{array}$ & $\begin{array}{l}\text { 90-day } \\
\text { VaR }\end{array}$ & $\begin{array}{l}\text { 90-day } \\
\text { ES-VaR }\end{array}$ & $\begin{array}{l}\text { 90-day } \\
\text { S-VaR }\end{array}$ \\
\hline 95 & 23.1 & 28.7 & 32.0 & 12.9 & 15.4 & 17.1 & 7.3 & 7.8 & 8.1 \\
97.5 & 29.6 & 32.1 & 33.8 & 15.4 & 17.0 & 18.2 & 7.8 & 8.1 & 8.5 \\
99 & 32.0 & 33.9 & 36.8 & 17.1 & 18.0 & 18.4 & 8.1 & 8.4 & 8.7 \\
99.99 & 36.8 & 36.8 & 36.8 & 18.4 & 18.4 & 18.4 & 8.7 & 8.7 & 8.7 \\
\hline
\end{tabular}

Notes:

1. ES-VaR is the simple mean of losses in the right tail beyond the VaR cutoff

2. S-VaR is VaR among the worst $20 \%$ of losses

are reported in Table 8. As the tables make clear, the VaR estimates are robust in terms of our main conclusion: the RBI's core capital base of 6.6 percent is probably less than half of what it should be. In fact, even the 90-day horizon VaR estimates at all confidence intervals are greater than the current core capital ratio of the RBI.

The results also illustrate the importance of using as much data as possible for computing VaRs since any single year may be atypical in terms of the return profile that it generated. As is easy to see from Tables 7 and 8, the computed VaR's at all horizons and confidence intervals are increasing in the sample period that we used. That just reflects the fact that the longer time periods included more negative shocks to returns relative to, say, only the 2017-18 sample.

It is important to note that our VaR estimates are higher than the estimates reported in the work of Anand et al. (2018) across the board. The reasons for differences between our estimates and their's are threefold: (a) our estimates do not include the exchange rate risk to asset values; (b) our estimates are based on a fiveyear time period from 2013 to 2018 to compute the VaR. This time period may be different from the sample period used by Anand et al. (2018) since they never explicitly report the sample period that they used; and (c) our VaR estimates are based on the clean price index of the various government securities while Anand et al. (2018), like with their sample time period silence, never explicitly state the bond price series that they use. ${ }^{9}$

We made the crucial conceptual and analytical choice of not including exchange rate risk while deriving the estimates for VaR of the RBI asset base. How much of a difference does this make? Conceptually, one can anticipate that it might make a difference depending on the sample one is using. Recall that a rupee appreciation reduces the value of foreign assets while a depreciation raises the value. Thus, a researcher who only considers a sample period in which the rupee depreciated (say 2017-18 for India) would not find any negative return episodes on account of exchange rate fluctuations. Contrarily, a researcher who considers a longer sample

\footnotetext{
9 From our attempts at reverse engineering their results, our best guess is that they just used a simple price that is the inverse of the gross interest factor on the asset. Moreover, the estimated results come closest to the ones that they report for the sample period April 2017-March 2018. The tables in the "Appendix" try to illustrate this.
} 
Table 9 VaR with exchange rate risk, as percent of total assets, January 2013-November 2018

\begin{tabular}{llllllllll}
\hline CI & $\begin{array}{l}\text { 10-day } \\
\text { VaR }\end{array}$ & $\begin{array}{l}\text { 10-day } \\
\text { ES-VaR }\end{array}$ & $\begin{array}{l}\text { 10-day } \\
\text { S-VaR }\end{array}$ & $\begin{array}{l}\text { 30-day } \\
\text { VaR }\end{array}$ & $\begin{array}{l}\text { 30-day } \\
\text { ES-VaR }\end{array}$ & $\begin{array}{l}\text { 30-day } \\
\text { S-VaR }\end{array}$ & $\begin{array}{l}\text { 90-day } \\
\text { VaR }\end{array}$ & $\begin{array}{l}\text { 90-day } \\
\text { ES-VaR }\end{array}$ & $\begin{array}{l}\text { 90-day } \\
\text { S-VaR }\end{array}$ \\
\hline 95 & 54.4 & 88.7 & 90.6 & 19.0 & 27.4 & 30.0 & 8.8 & 11.3 & 12.5 \\
97.5 & 69.5 & 115.7 & 142.8 & 24.8 & 33.3 & 38.9 & 10.6 & 12.9 & 13.9 \\
99 & 90.6 & 170.6 & 204.2 & 30.0 & 41.8 & 52.4 & 12.5 & 15.0 & 17.2 \\
99.99 & 533.6 & 533.6 & 533.6 & 73.1 & 73.1 & 73.1 & 23.3 & 23.3 & 23.3 \\
\hline
\end{tabular}

Notes:

1. ES-VaR is the simple mean of losses in the right tail beyond the VaR cutoff

2. S-VaR is VaR among the worst $20 \%$ of losses

Table 10 VaR with exchange rate risk, as percent of total assets, April 2017-November 2018

\begin{tabular}{llllllllll}
\hline CI & $\begin{array}{l}\text { 10-day } \\
\text { VaR }\end{array}$ & $\begin{array}{l}\text { 10-day } \\
\text { ES-VaR }\end{array}$ & $\begin{array}{l}\text { 10-day } \\
\text { S-VaR }\end{array}$ & $\begin{array}{l}\text { 30-day } \\
\text { VaR }\end{array}$ & $\begin{array}{l}\text { 30-day } \\
\text { ES-VaR }\end{array}$ & $\begin{array}{l}\text { 30-day } \\
\text { S-VaR }\end{array}$ & $\begin{array}{l}\text { 90-day } \\
\text { VaR }\end{array}$ & $\begin{array}{l}\text { 90-day } \\
\text { ES-VaR }\end{array}$ & $\begin{array}{l}\text { 90-day } \\
\text { S-VaR }\end{array}$ \\
\hline 95 & 25.2 & 30.4 & 33.2 & 14.8 & 18.2 & 20.8 & 10.2 & 11.9 & 13.3 \\
97.5 & 29.8 & 34.0 & 33.8 & 16.5 & 21.1 & 23.4 & 11.2 & 13.3 & 14.0 \\
99 & 33.2 & 36.7 & 43.3 & 20.8 & 25.8 & 28.2 & 13.3 & 13.9 & 14.4 \\
99.99 & 43.3 & 43.3 & 43.3 & 28.2 & 28.2 & 28.2 & 14.4 & 14.4 & 14.4 \\
\hline
\end{tabular}

Notes:

1. ES-VaR is the simple mean of losses in the right tail beyond the VaR cutoff

2. S-VaR is VaR among the worst $20 \%$ of losses

such as 2013-18 that included periods of rupee appreciation would find negative return episodes due to exchange rate fluctuations and consequently will estimate a higher VaR.

To examine this we incorporate exchange rate risk as well and recompute the VaRs at all horizons, frequencies and confidence intervals. Tables 9 and 10 below report the results for the full sample and for the 2017-18 sample period, respectively.

As anticipated, considering longer time periods that include periods when the rupee appreciated raises the estimated VaR for the 10- and 30-day horizons for all confidence intervals and methods. As an example, the estimated 30-day S-VaR under the 95 percent confidence interval for the 2017-18 sample period is 20.8 percent. When the sample period considered is broadened to the entire 2013-18 period, the estimated $\mathrm{S}-\mathrm{VaR}$ at the 95 percent confidence interval rises to 30 percent, a number that is even greater than the 27 percent consolidated capital base including the entire revaluation capital of the RBI!

There are two main takeaways from the above. First, the estimated VaR for the RBI asset portfolio is quite high under all methods, horizons and confidence intervals. Indeed, our estimates excluding exchange rate risk suggest that the RBI's core capital needs to be well above 16 percent, which is more than double its current level of 6.6 percent. Second, including exchange rate risk raises the VaR estimates as long as one also includes periods where the exchange rate appreciated rather than only depreciating. Importantly, our S-VaR estimate including exchange rate risk is 30 
percent for the 30-day horizon at the 95 percent confidence interval. This is almost 3 percentage points greater than the total capital of the RBI currently. Indeed, even the ES-VaR estimate at the 95 percent confidence interval for the 30-day horizon is 27.4 percent. The corresponding number for the 10-day horizon is a whopping 88.7 percent. Hence, independent of whether or not one includes exchange rate risk or not, the RBI's relevant capital base needs to be increased, not reduced.

\section{Fiscal payouts of excess capital and policy moral hazard}

There are some non-trivial policy moral hazard issues associated with the central bank capital structure that are worth pointing out. Stipulating a strictly mandated level for total central bank capital (including revaluation capital and core capital) could induce demands for special dividend payments to the fiscal authority when the central bank's capital rises above the stipulated target. Such payments would either increase fiscal spending directly and potentially compromise the central bank's inflation target or, when commercial banks are publicly owned, raise the credit in the economy which would compromise the central bank's liquidity and credit targets. In anticipation of such payment demands, central banks could respond by deviating from their preferred monetary policy in order to avoid paying out this one-time excess capital cess.

One example of this is interest rate policy. A lower policy rate that is transmitted through the economy causes the value of central bank domestic assets to rise. Hence, a central bank could try and prevent a rise in its capital levels above the stipulated threshold by not reducing policy rates by as much as they would have in the absence of such a mandated threshold. A second example is exchange rate policy. Since a depreciation of the local currency causes total capital of the central bank to rise, a central bank could try and avoid the resultant demand for payments to the fiscal authority by preventing the currency depreciation. But this would compromise the central bank's policy mandate of targeting growth and external balance.

Both of these are examples where mandating a strict capital level with associated expectations of special dividend payments of the excess capital would compromise the central bank's operational independence to achieve its policy mandate. While determining the optimal capital base of the central bank is a desirable goal, it is also important that this does not introduce conflicts in the central bank's policy mandates. A few of methods to achieve this are:

1. Compute the actual capital level as a 3 -year moving average when evaluating its level relative to the agreed capital target. Moreover, there should be a band around the capital target with the moving average of central bank capital expected to remain within the bounds. Violation of the upper and lower threshold bounds should induce at least a 1-year period in which the central bank is expected to bring the moving average back to within the bound.

2. Only target core capital (excluding revaluation capital) since this will leave the central bank to pursue its exchange rate policy unencumbered by considerations 
of their effect on the value of its overall capital (including revaluation capital) relative to the mandated capital threshold.

3. Payments of any excess average capital holdings need to be made in a phased manner rather than a one-time payout. The least distortionary method of making such payments is by gradually retiring some of the public debt that the central bank typically holds. This does not have a direct inflationary impact since it avoids directly generating revenue for the fiscal authority.

\section{Conclusion}

In this paper, we have analyzed the empirical and conceptual issues surrounding the capital-asset ratios of central banks. Our analysis of the capital structure of central banks around the world focused on deployable capital, or capital that can be put to immediate use in the event of an emergency. To do so, we put aside the revaluation capital that a number of central banks carry on their balance sheets. Revaluation capital is an accounting entry that is used to accommodate changes in the domestic currency value of foreign assets due to changes in the exchange rate and gold prices.

Our empirical examination of the core capital of 45 central banks from around the world suggests that the RBI's core capital ratio (excluding the Asset Development Fund) in 2018 was about 5 percent lower than the emerging economy average. After the implementation of the Jalan committee report, it has become even lower. Low capital reserves create two problems. First, they compromise the ability of a central bank to manage risks. Second, negative income shocks can push the central bank into negative equity territory which could further compromise the banks operational capability. We find that negative income shocks among central banks are fairly common. In any given year, more than one in seven central banks have negative surpluses with the number rising to one in five in some years. Moreover, the average size of these negative income shocks were large enough to wipe out 50 percent of the core capital of the concerned central bank. Negative income shocks are not a rarity in India: the time series behavior of surpluses of the RBI over the last 20 years indicate that a negative income shock of 1.29 standard deviations would have been enough to create income losses in 2008 and 2017.

Given that central banks are owned by national governments, it is reasonable to question the need for capital buffers for central banks along the lines of commercial banks. Indeed, one might argue that during emergencies the government could inject capital into the central bank to allow it to perform its regulatory and prudential functions. However, this possibility depends crucially on the health of government finances. The consolidated fiscal deficit in India is 65 percent more than the average fiscal deficit among emerging economies and 128 percent greater than the international average. Clearly, relying on injections of resources from a government running such a high deficit would seem to be risky if not improbable.

To answer the original question on the optimal size of the central bank balance sheet, we conducted a VaR estimation for the RBI balance sheet based on data for the period January 2013-November 2018. Our estimates, for all confidence intervals, all methods and all time horizons suggest that the target number for the RBI 
core capital should be above 16 percent, which is more than double the upper limit of the range for the core capital ratio suggested by the Jalan committee. Moreover, once one includes exchange rate risk in the $\mathrm{VaR}$ computations, we find that the RBI's overall capital base including revaluation capital needs to be closer to 30 percent. Our primary conclusion is that the RBI is certainly not over-capitalized. Rather, its capital ratio (certainly the core capital but probably the overall capital ratio as well) needs to be raised.

At a more conceptual level, there may be well defined political economy reasons to park some of the consolidated government's assets in a protected entity like the central bank to build fiscal credibility of the country. It also gives the central bank greater credibility in committing to perform it's emergency functions without worrying about the fiscal contingencies of its ultimate owner. Hence, the role for central bank equity must ultimately be based on political economy arguments. This is also the reason why cross-country comparisons of central bank capital structure are ultimately limited in their usefulness.

In terms of policy conclusions, we believe that mandating payouts from the excess capital of the central bank is a problematic idea. This was recommended by the Jalan committee. While it may be a benign move if used as a one-off move to bring the RBI's core capital into the recommended range, it can create a policy moral hazard if the central bank is mandated to transfer all excess capital every time the core capital exceeds the recommended range. Since core policy decisions like monetary policy and exchange rate policy affect the value of central bank assets and, hence, its equity, in anticipation of payout demands based on capital value the central bank may try to adjust its policy action. This will compromise the central bank's operational independence to achieve it's policy mandate.

In light of the above, payouts based on the difference between the actual and the target equity level should be taken off the possibility set. The Jalan committee explicitly recommended against payouts from the revaluation capital of the RBI. This clause should be extended to payouts from the core capital as well. Thus, a formal agreement between the government and the central bank should not just stipulate a target band for the equity level of the central bank but also explicitly eliminate the possibility of payouts from the core capital. In the event of core capital exceeding the upper bound of the target range, the agreement should stipulate some time frame within which the central bank has to bring back its core equity into the target range.

\section{Appendix}

In this data appendix, we outline our data sources, the methods we use to separate core capital from overall capital, and the effect of choosing different time periods on the estimated VaRs. 


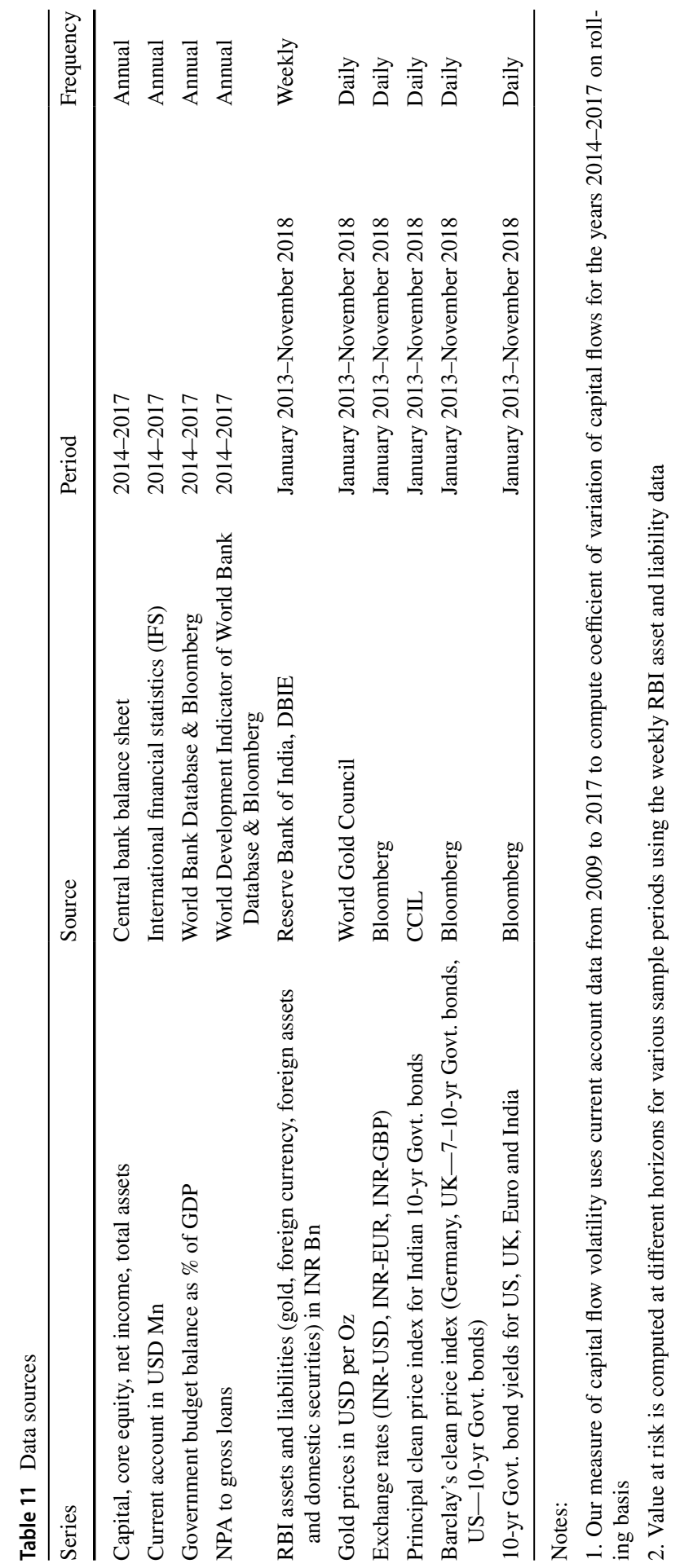




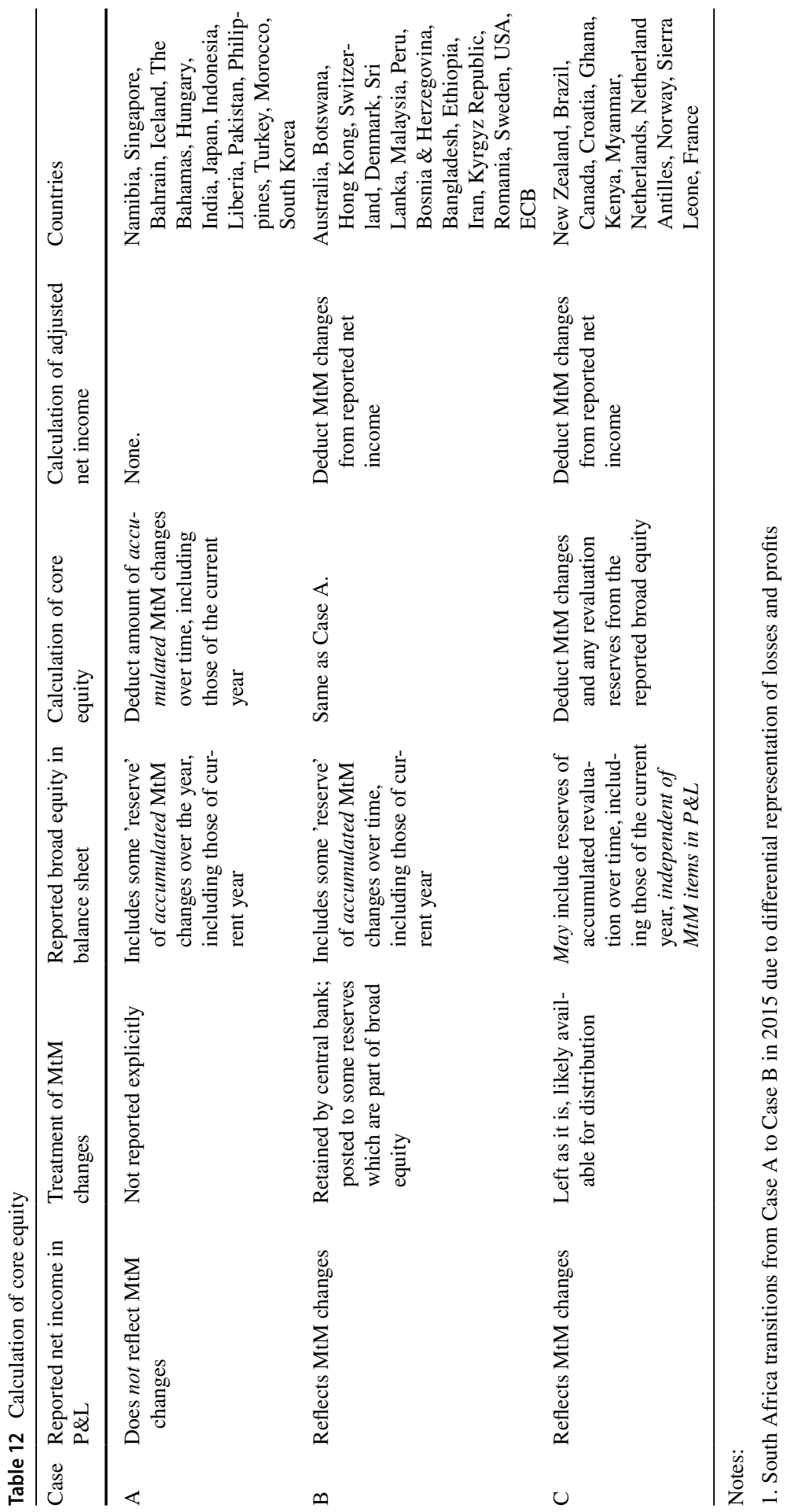


Table 13 Capital required to cover market risk, as percent of total assets, April 2017-March 2018

\begin{tabular}{llllllllll}
\hline CI & $\begin{array}{l}\text { 10-day } \\
\text { VaR }\end{array}$ & $\begin{array}{l}\text { 10-day } \\
\text { ES-VaR }\end{array}$ & $\begin{array}{l}\text { 10-day } \\
\text { S-VaR }\end{array}$ & $\begin{array}{l}\text { 30-day } \\
\text { VaR }\end{array}$ & $\begin{array}{l}\text { 30-day } \\
\text { ES-VaR }\end{array}$ & $\begin{array}{l}\text { 30-day } \\
\text { S-VaR }\end{array}$ & $\begin{array}{l}\text { 90-day } \\
\text { VaR }\end{array}$ & $\begin{array}{l}\text { 90-day } \\
\text { ES-VaR }\end{array}$ & $\begin{array}{l}\text { 90-day } \\
\text { S-VaR }\end{array}$ \\
\hline 95 & 23.9 & 29.8 & 33.8 & 14.2 & 16.7 & 18.2 & 7.6 & 8.0 & 8.5 \\
97.5 & 29.9 & 33.2 & 34.6 & 16.9 & 17.7 & 18.2 & 8.0 & 8.3 & 8.6 \\
99 & 33.8 & 35.0 & 36.8 & 18.2 & 18.3 & 18.4 & 8.5 & 8.6 & 8.7 \\
99.99 & 36.8 & 36.8 & 36.8 & 18.4 & 18.4 & 18.4 & 8.7 & 8.7 & 8.7 \\
\hline
\end{tabular}

Notes:

1. ES-VaR is the simple mean of losses in the right tail beyond the VaR cutoff

2. S-VaR is VaR among the worst $20 \%$ of losses

Table 14 VaR with exchange rate risk, as percent of total assets, April 2017-March 2018

\begin{tabular}{llllllllll}
\hline CI & $\begin{array}{l}\text { 10-day } \\
\text { VaR }\end{array}$ & $\begin{array}{l}\text { 10-day } \\
\text { ES-VaR }\end{array}$ & $\begin{array}{l}\text { 10-day } \\
\text { S-VaR }\end{array}$ & $\begin{array}{l}\text { 30-day } \\
\text { VaR }\end{array}$ & $\begin{array}{l}\text { 30-day } \\
\text { ES-VaR }\end{array}$ & $\begin{array}{l}\text { 30-day } \\
\text { S-VaR }\end{array}$ & $\begin{array}{l}\text { 90-day } \\
\text { VaR }\end{array}$ & $\begin{array}{l}\text { 90-day } \\
\text { ES-VaR }\end{array}$ & $\begin{array}{l}\text { 90-day } \\
\text { S-VaR }\end{array}$ \\
\hline 95 & 30.6 & 45.3 & 50.3 & 14.9 & 21.9 & 27.5 & 8.7 & 10.9 & 12.5 \\
97.5 & 43.3 & 53.6 & 62.5 & 20.8 & 27.8 & 30.5 & 10.6 & 12.2 & 13.3 \\
99 & 50.3 & 62.1 & 74.5 & 27.5 & 31.6 & 37.1 & 12.5 & 13.7 & 14.4 \\
99.99 & 74.5 & 74.5 & 74.5 & 37.1 & 37.1 & 37.1 & 14.4 & 14.4 & 14.4 \\
\hline
\end{tabular}

Notes:

1. ES-VaR is the simple mean of losses in the right tail beyond the VaR cutoff

2. S-VaR is VaR among the worst $20 \%$ of losses

\section{Data sources}

Our data comes from various sources which are detailed in Table 11.

\section{Accounting method}

To compute the core equity of all the central banks in our sample, we conducted a detailed reading of the individual central bank balance sheets before making the appropriate adjustments. Our calculation methods are outlined in Table 12.

\section{Shorter time periods and estimated VaRs}

To compare our results with Anand et al. (2018), we computed the VaRs over the sample period April 2017 to March 2018. This sample period gave us numbers that are closest to the VaR estimates reported in Anand et al. (2018). Tables 13 and 14 report the results. 


\section{References}

Adler, G., Castro, P. \& Mora, C. (2012). Does Central Bank Capital Matter for Monetary Policy. In IMF Working Papers 12/60, International Monetary Fund.

Anand, A., Fellman, J., Sharma, N., \& Subramanian, A. (2018). Paranoia or prudence? Economic and Political Weekly, 53, 48.

Ize, A. (2006). Spending Seigniorage; Do Central Banks Have a Governance Problem? In IMF Working Papers 06/58, International Monetary Fund.

Klueh, U. H. \& Stella, P. (2008). Central bank financial strength and policy performance; an econometric evaluation. In IMF Working Papers 08/176, International Monetary Fund.

Oulidi, N. \& Ize, A. (2009). Why do central banks go weak? In IMF Working Papers 09/13, International Monetary Fund.

Stella, P. (1997). Do central banks need capital. In IMF Working Papers 97/83, International Monetary Fund.

Stella, P. (2008). central bank financial strength, policy constraints and inflation. In IMF Working Papers 08/49, International Monetary Fund.

Publisher's Note Springer Nature remains neutral with regard to jurisdictional claims in published maps and institutional affiliations. 